\title{
Aging Increased Amyloid Peptide and Caused Amyloid Plaques in Brain of Old APP/V717I Transgenic Mice by a Different Mechanism than Mutant Presenilin1
}

\author{
Ilse Dewachter, ${ }^{1}$ Jo Van Dorpe, ${ }^{1}$ Liesbet Smeijers, ${ }^{1}$ Martine Gilis, ${ }^{1}$ Cuno Kuipéri, ${ }^{1}$ Isabelle Laenen, ${ }^{1}$ \\ Nathalie Caluwaerts, ${ }^{1}$ Dieder Moechars, ${ }^{4}$ Frédéric Checler, ${ }^{2}$ Hugo Vanderstichele, ${ }^{3}$ and Fred Van Leuven ${ }^{1}$ \\ ${ }^{1}$ Experimental Genetics Group, Center for Human Genetics, Flemish Institute for Biotechnology, Katholieke Universiteit \\ Leuven, B-3000 Leuven, Belgium, 2Institut de Pharmacologie Moléculaire et Cellulaire/Centre National de la Recherche \\ Scientifique, Unité Propre de Recherche 411, Valbonne 06560, France, 3/nnogenetics NV, Industriepark Zwijnaarde, 9052

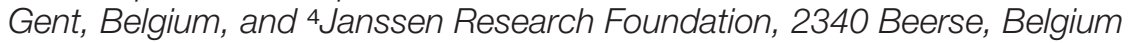

\begin{abstract}
Aging of transgenic mice that overexpress the London mutant of amyloid precursor protein (APP/V717I) (Moechars et al., 1999a) was now demonstrated not to affect the normalized levels of $\alpha$ or $\beta$-cleaved secreted APP nor of the $\beta$-C-terminal stubs. This indicated that aging did not markedly disturb either $\alpha$ - or $\beta$-secretase cleavage of APP and failed to explain the origin of the massive amounts of amyloid peptides $A \beta 40$ and $A \beta 42$, soluble and precipitated as amyloid plaques in the brain of old APP/N717I transgenic mice. We tested the hypothesis that aging acted on presenilin1 (PS1) to affect $\gamma$-secretase-mediated production of amyloid peptides by comparing aged APP/V717I transgenic mice to double transgenic mice coexpressing human PS1 and APP/V717I. In double transgenic mice with mutant (A246E) but not wild-type human PS1, brain amyloid peptide levels increased and resulted in amyloid plaques when the mice were only 6-9 months old, much earlier than in APP/V717I transgenic mice (12-15 months old). Mutant PS1 increased mainly
\end{abstract}

brain $A \beta 42$ levels, whereas in aged APP/N717I transgenic mice, both $A \beta 42$ and $A \beta 40$ increased. This resulted in a dramatic difference in the $A \beta 42 / A \beta 40$ ratio of precipitated or plaqueassociated amyloid peptides, i.e., $3.11 \pm 0.22$ in double APP/ V717I $\times$ PS1/A246E transgenic mice compared with $0.43 \pm 0.07$ in aged APP/V717I transgenic mice, and demonstrated a clear difference between the effect of aging and the effect of the insertion of a mutant PS1 transgene. In conclusion, we demonstrate that aging did not favor amyloidogenic over nonamyloidogenic processing of APP, nor did it exert a mutant PS1-like effect on $\gamma$-secretase. Therefore, the data are interpreted to suggest that parenchymal and vascular accumulation of amyloid in aging brain resulted from failure to clear the amyloid peptides rather than from increased production.

Key words: amyloid precursor protein; APP processing; aging; presenilin; transgenic mice; amyloid plaques; amyloid peptide
Amyloid peptides accumulate in parenchymal plaques and vascular deposits that constitute the major postmortem pathological hallmark of Alzheimer's disease (AD). Clinical mutations in the genes coding for amyloid precursor protein (APP) or presenilins (PS1 and PS2) cause early-onset familial AD (EOFAD) (Hardy, 1997; Selkoe, 1998) and affect the proteolytic processing of APP directly to yield more amyloidogenic peptides. However, EOFAD accounts for only a minority of $\mathrm{AD}$ cases, while aging remains the most prevailing risk factor for AD. The effect of the mutations on the processing of APP and on amyloid peptide formation has been extensively studied in cells and models, including transgenic mice. The effects of aging remain, however, less well explored.

Different transgenic mice that overexpress wild-type (wt) or mutant (Mut) APP, PS1, or PS2 have been generated and some recapitulate the amyloid aspects of AD pathology very well, although lacking neurofibrillary tangles. In principle, these models allow analysis of the effect of aging on APP processing and its role

\footnotetext{
Received May 31, 2000; accepted June 16, 2000.

This investigation was supported by the Fonds voor Wetenschappelijk OnderzoekVlaanderen, by Nationaal Fonds voor Wetenschappeligh Onderzsek-Lotto, by the Interuniversity Attraction Pole program, by the Action Program for Biotechnology (Instituut voor Wetenschap en Technologie/Vlaamse Actiecommissie voor Biotechnologie, COT-008), by the 4th Framework European Economic CommissionBiotechnology program, by the Rooms-fund, by Janssen Research Foundation, and by Leuven Research and Development. The intellectual and material contributions of the following scientists are gratefully acknowledged: L. Serneels, K. Meurrens, B.Greenberg, K. Beyreuther, P. St George-Hyslop, E. Van Mechelen, A. Van de Voorde, W. Annaert, P. Seubert, and H. Van der Putten.

Correspondence should be addressed to Dr. Fred Van Leuven, Experimental Genetics Group, Center for Human Genetics, Flemish Institute for Biotechnology, Katholieke Universiteit Leuven, Campus Gasthuisberg O\&N 06, B-3000 Leuven, Belgium. E-mail: fredvl@med.kuleuven.ac.be.

Copyright (C) 2000 Society for Neuroscience $0270-6474 / 00 / 206452-07 \$ 15.00 / 0$
}

in amyloid peptide accumulation and deposition. Double transgenic mice that coexpress APP and presenilin demonstrated that PS1 mutants essentially increase production of $\mathrm{A} \beta 42$ (Borchelt et al., 1996; Duff et al., 1996; Citron et al., 1997) and cause early development of amyloid plaques as in EOFAD (Borchelt et al., 1997; Holcomb et al., 1998) as originally observed in cell biological models (for review, see Selkoe, 1998).

Previously, we have generated and characterized transgenic mice that overexpress human APP in their central neurons, causing early behavioral and phenotypic changes, including cognitive impairment with decreased long-term potentiation (Moechars et al., 1996, 1998a,b, 1999a,b). For further studies, we have selected the transgenic mouse line that overexpressed the "London" mutant of APP (APP/V717I) (for review, see Hardy, 1997) because these develop later in life abundant amyloid plaques in brain parenchyma (Moechars et al., 1999a), as well as vascular deposits (Van Dorpe et al., 2000).

In the current study, we have biochemically analyzed the effect of aging on the pathologically relevant derivatives of APP in the brain of APP/V717I transgenic mice. Increase in the soluble and precipitated amyloid peptides $\mathrm{A} \beta 40$ and $\mathrm{A} \beta 42$ and in the $\mathrm{A} \beta 42 / \mathrm{A} \beta 40$ ratio was marked between the ages of 12 and 15 months. Aging did not, however, alter the normalized levels of either $\alpha$ - or $\beta$-secretase-cleaved APP (APPs $\alpha$ and APPs $\beta$ ) nor those of the C-terminal "stubs" resulting from $\beta$-cleavage of APP ( $\beta$-C stubs). This excluded a major alteration in relative $\alpha$ - and $\beta$-secretase cleavage of APP as the cause of amyloid accumulation in aging brain.

Because $\gamma$-secretase is controlled by or identical to PS1 (De Strooper et al., 1998; Wolfe et al., 1999; Kimberly et al., 2000; Li et al., 2000; Selkoe and Wolfe, 2000), we have comparatively analyzed 
A

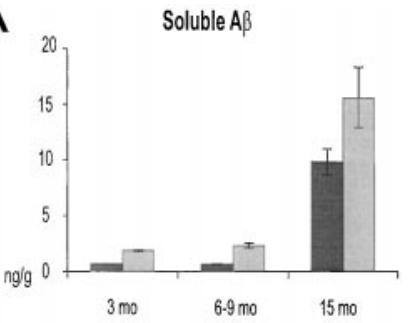

B

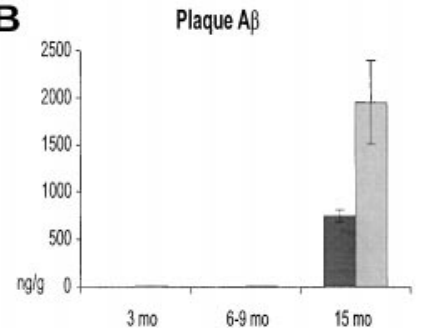

Ratio soluble $A B 42 / 40$

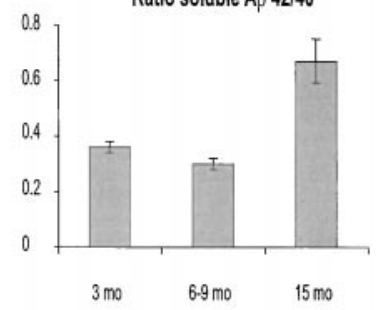

Ratio plaque $A \beta 42 / 40$

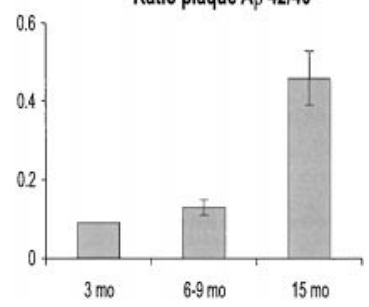

Figure 1. Soluble and insoluble amyloid peptides in brain of aging APP/ V717I transgenic mice. Concentrations of soluble $(A)$ and precipitated or plaque-associated $(B)$ amyloid peptides, i.e., $\mathrm{A} \beta 40$ (gray bars) and $\mathrm{A} \beta 42$ (black bars), were measured by specific ELISA, and results are expressed as nanogram peptide per gram brain tissue. The ratio of the concentrations, i.e., A $\beta 42 / \mathrm{A} \beta 40$ of both soluble and precipitated amyloid peptides, was calculated ( $A$ and $B$, right $)$. All histograms represent the mean with SEM of at least four transgenic mice in each age group.

the effect of aging and the effect of PS1 on amyloid peptide accumulation. In the brain of double transgenic mice, i.e., APP/ V717I $\times$ PS1/A246E, we observed mainly an increase in A $\beta 42$, resulting in earlier plaque formation, by predominant $\mathrm{A} \beta 42$ deposition. In contrast, both $\mathrm{A} \beta 40$ and $\mathrm{A} \beta 42$ peptides increased with aging, and $\mathrm{A} \beta 40$ peptides remained the most preponderant precip-

itated peptide in brain of aged APP/V717I transgenic mice. Combined, this resulted in an $\sim 10$-fold difference in the $\mathrm{A} \beta 42 / \mathrm{A} \beta 40$ ratio of precipitated amyloid peptides in double transgenic mice compared with aged APP/V717I transgenic mice. Because aging did not affect $\alpha$ - or $\beta$-secretase cleavage or exert a presenilin mutant-like effect on $\gamma$-secretase, we hypothesize that the accumulation of amyloid was attributable to failing clearance and degradation in aging brain.

\section{MATERIALS AND METHODS}

Transgenic mice. All transgenic mice used in this study were of the FVB/N genetic background and expressed APP/V717I, PS1, or both under control of the mouse thy 1 gene promoter. The APP/V717I transgenic mice (Moechars et al., 1999a) and the PS1 transgenic mice were derived essentially as described previously (Moechars et al., 1996). Briefly, cDNA coding for wild-type human PS1 and mutant PS1/A246E were blunted and ligated into a XhoI site created in an adapted mouse thy1 gene (Moechars et al., 1996). In the final construct, coding sequences and introns 2 and 3 of the mouse thyl gene are replaced, leaving the $5^{\prime}$ neuron-specific control elements intact. Linearized mini-gene constructs were microinjected into prenuclear embryos from superovulated $\mathrm{FVB} / \mathrm{N}$ females and transgenic founders identified by Southern blotting of tail-biopt DNA by standard procedures (Moechars et al., 1996). Transgenic strains that transmitted the transgene in a strictly mendelian manner without integration-site effects were compared, and high expressing strains were selected after Western blotting of brain extracts. Double transgenic mice overexpressing APP/V717I and either PS1/mutant or PS1/wt were obtained by crossbreeding of single APP/V717I and PS1 mutant or wild-type transgenic mice.

Biochemical analysis of transgenic mouse brain. Brains of heterozygous APP/V717I transgenic mice or of double transgenic APP/V717I $\times$ PS1 mice were prelevated. One hemisphere was snap-frozen in liquid nitrogen for biochemical analysis, and the other hemisphere was fixed in $4 \%$ paraformaldehyde for immunohistochemistry. Differential extraction was performed to isolate fractions containing soluble proteins, membrane proteins, and insoluble or "plaque"-associated proteins. To this end, individual hemispheres were homogenized in 6.5 vol of ice-cold buffer containing $20 \mathrm{~mm}$ Tris- $\mathrm{HCl}, \mathrm{pH} 8.5$, and a cocktail of proteinase inhibitors (Boehringer Mannheim, Mannheim, Germany) using a small potter-type mechanical homogenizer. After centrifugation $(135,000 \times g$ for $1 \mathrm{hr}$ at $\left.4^{\circ} \mathrm{C}\right)$, a portion of the supernatant was cleared again $(200,000 \times g$ for $2 \mathrm{hr}$ at $4^{\circ} \mathrm{C}$ ) before analysis of soluble amyloid peptides by specified ELISA.
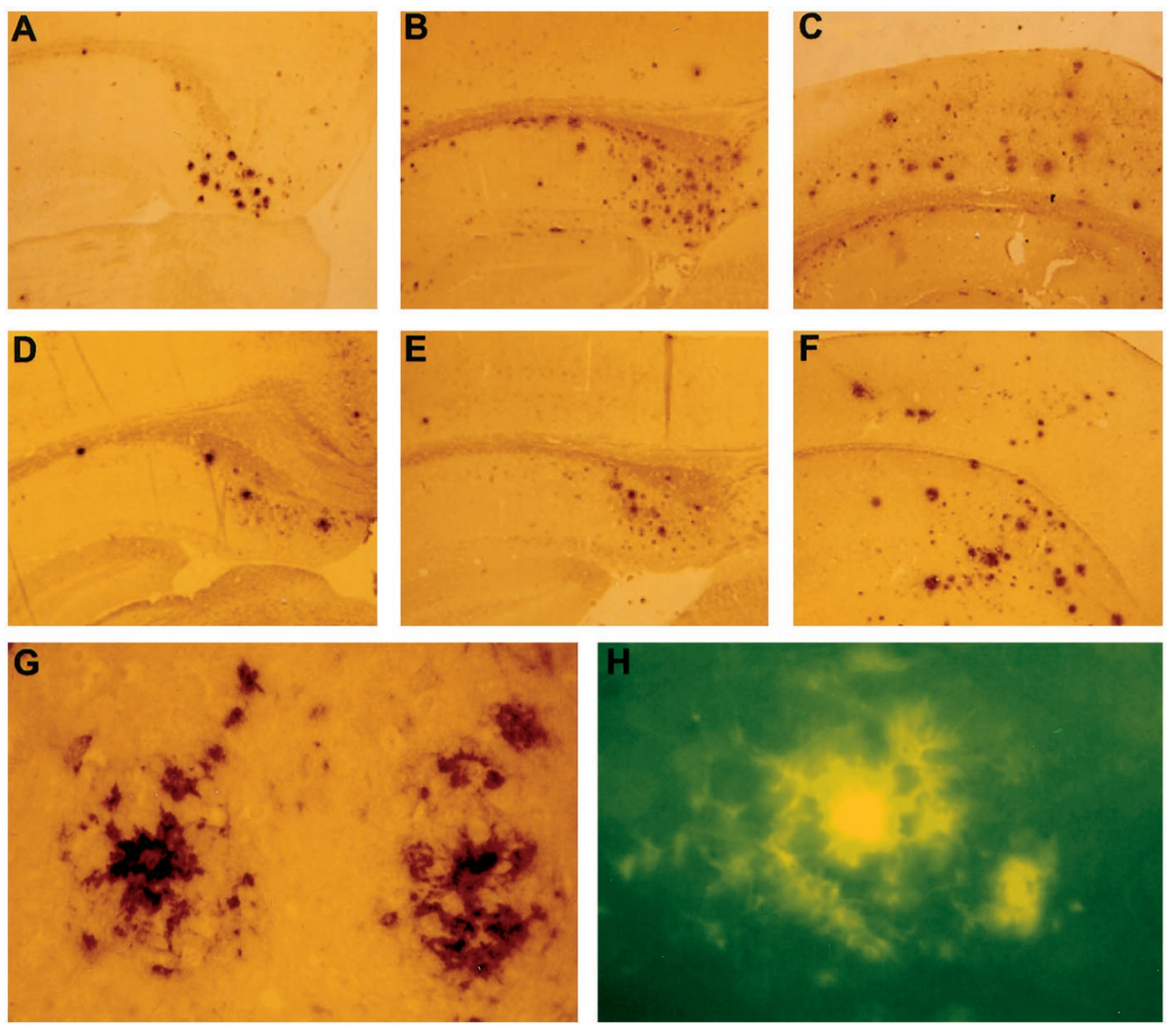

Figure 2. Immunohistochemical staining with antibody FCA18 of brain sections of single APP/V717I transgenic mice and double APP/V717I $\times$ PS1/A246E transgenic mice. Amyloid plaques in subiculum of double transgenic mouse at 8 months of age $(A)$ and in subiculum $(B)$ and cortex $(C)$ at 13 months of age. Amyloid plaques in subiculum $(D)$ of APP/V717I transgenic mouse (15 months) and in subiculum $(E)$ and cortex $(F)$ of APP/V717I transgenic mouse (18 months). $G$ is higher magnification to illustrate the typical neuritic plaques with a dense core as described previously (Moechars et al., 1999a; Van Dorpe et al., 2000). $H$ is an example of a typical thioflavine S-stained plaque, abundantly present in the brain of single and double transgenic mice (Van Dorpe et al., 2000). 
A

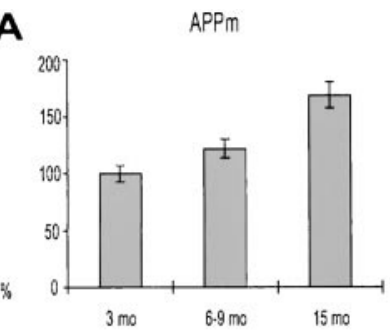

B

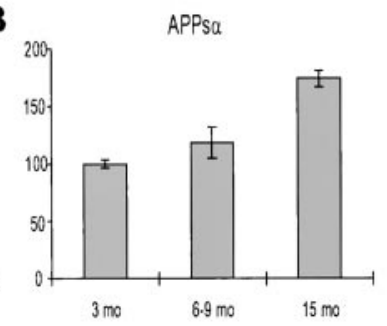

C

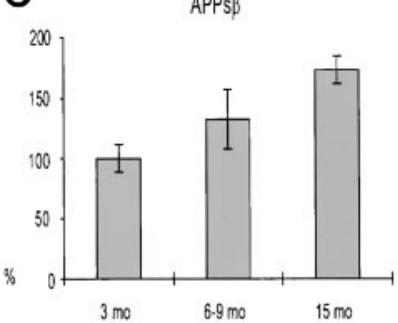

diates in brain of APP/V717I transgenic mice. Brain of heterozygous APP/V717I transgenic mice $(A P P)$ of different age groups was analyzed for the APP intermediates, indicated in each panel, by Western blotting with the indicated antibodies and representatively illustrated (right column). All the levels are expressed relative to those in brain of the youngest APP/V717I transgenic mice analyzed, i.e., 3 months old. In $A-D$, the primary concentrations as measured (left) were normalized to the level of expression of the membrane-bound APPm (middle). All histograms represent the mean with SEM of at least four transgenic mice in each age group. The Western blots also illustrate serial dilutions of a standardized pooled extract as applied on each gel to allow normalization.

D

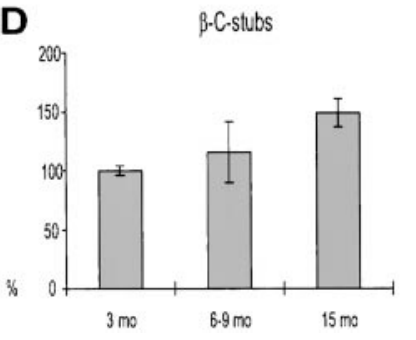

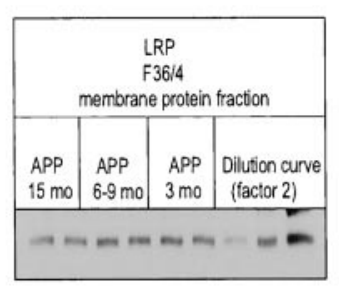
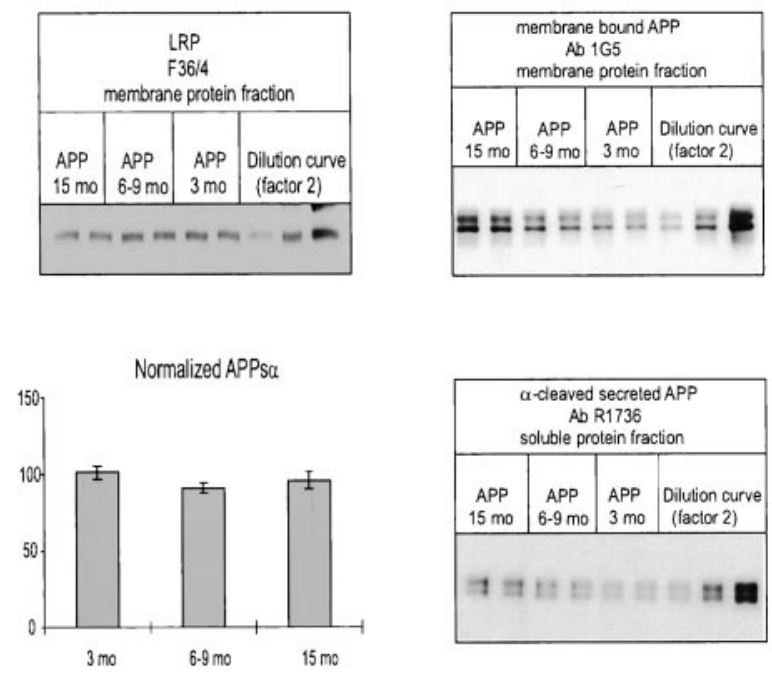

Nomalized APPS $\beta$
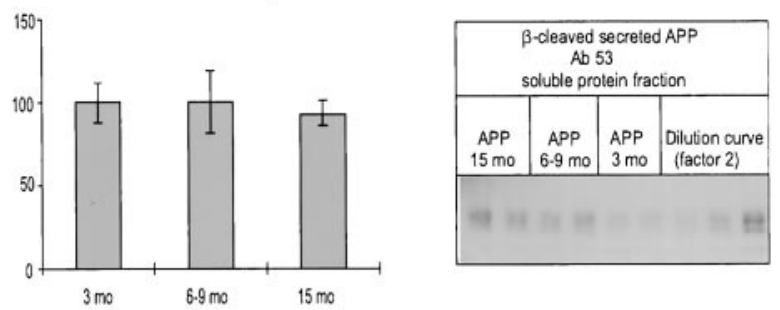

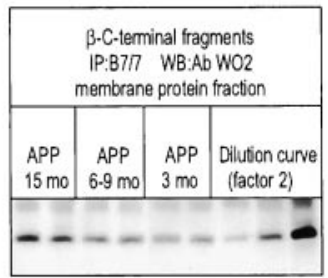

The pellet from the first centrifugation was resuspended and extracted in 15 vol of ice-cold buffer containing $10 \mathrm{~mm}$ Tris- $\mathrm{HCl}, \mathrm{pH} 7.6,150 \mathrm{mM}$ sodium chloride, $2 \%$ Triton X-100, $2 \%$ Nonidet P-40, and the cocktail of proteinase inhibitors. After centrifugation $\left(100,000 \times g\right.$ for $1 \mathrm{hr}$ at $\left.4^{\circ} \mathrm{C}\right)$ the supernatant ("membrane" fraction) was used for analysis of membranebound proteins, and the residual pellet was resuspended and extracted in guanidinium buffer with a final concentration of $50 \mathrm{~mm}$ Tris and $5 \mathrm{M}$ guanidinium chloride, $\mathrm{pH}$ 8.0. This extract was used to measure levels of insoluble or plaque-associated $\mathrm{A} \beta 40$ and $\mathrm{A} \beta 42$ levels by specified ELISA as detailed below.

Western blotting of membrane-bound APP, APPs $\alpha, A P P s \beta$, and the $\beta-C$ stubs. Biochemical analysis of intact membrane-bound APP (APPm) $\mathrm{APPs} \alpha, \mathrm{APPs} \beta$, and the $\beta$-C stubs was essentially performed as described previously (Moechars et al., 1999a) with minor modifications. APPm was measured on the membrane fraction by Western blotting with monoclonal antibody 1G5 (Athena Neurosciences, San Francisco, CA). APPs $\alpha$ was measured in the soluble protein fraction by Western blotting with the polyclonal antibody R1736, recognizing an epitope between the $\alpha$ - and $\beta$-secretase cleavage sites [amino acids (aa) 595-611] (Haass et al., 1992). APPs $\beta$ was detected in the soluble protein fraction by Western blotting with the polyclonal antibody Ab53 (Howland et al., 1995). Briefly, samples of the fractions were treated to contain at a final concentration $2 \%$ SDS and $1 \% 2$-mercaptoethanol (2-ME), and the proteins were denatured by incubation at $95^{\circ} \mathrm{C}$ for $10 \mathrm{~min}$. After separation on polyacrylamide gels (8\% Tris-glycine; Novex, San Diego, CA), proteins were electrophoretically transferred to nitrocellulose membranes (Hybond-ECL; Amersham Pharmacia Biotech, Little Chalfont, UK), and Western blotting was performed exactly as described previously (Moechars et al., 1999a). The $\beta-C$ stubs were immunoprecipitated from the membrane fraction with the polyclonal antibody B717 raised against the human amyloid peptide (aa 597-612) (De Strooper et al., 1995). After incubation overnight with antiserum and protein G-Sepharose, the collected pellets were washed, denatured, reduced, and separated on $4-12 \%$ Nu-Page gels (Novex). After transfer to nitrocellulose membranes, $\beta$-C stubs were detected by Western blotting with antibody WO2 (Ida et al. 1996). After incubation with appropriate secondary antibodies, all Western blots were developed with the ECL detection system and photographically recorded (Hyperfilm; Amersham Pharmacia Biotech, Little Chalfont, UK). Quantitative analysis was performed by application on each gel of at least three serial dilutions of a standardized pooled extract treated exactly as the experimental samples, allowing standardization and normalization between gels and between experiments.

Densitometric scanning of films and calculation and normalization was performed as described previously (Moechars et al., 1999a) using a flatbed optical density scanner and dedicated software for analysis and measurement (Image Master; Amersham Pharmacia Biotech, Uppsala, Sweden). In all experiments and assays, extraction of membrane proteins from brain was additionally verified by measuring the membrane-bound $85 \mathrm{kDa}$ subunit of the low density lipoprotein receptor-related protein (LRP) as an internal control. LRP is a membrane protein unrelated to APP and also ubiquitously expressed in brain. The specific antiserum F36/4 was raised against a synthetic peptide representing the ultimate 12 amino acids from its C-terminal domain.

Western blotting of neprilysin and presenilin1. For detection of neprilysin, proteins of the membrane protein fraction were denatured and reduced by boiling in sample buffer containing 2\% SDS and 1\% 2-ME and separated on an $8 \%$ Tris-glycine gel (Novex). Detection was done by Western blotting with the monoclonal antibody 56C6 (Novocastra Laboratories, Newcastle upon Tyne, UK) (Iwata et al., 2000). For detection of PS1 protein, brains were homogenized in sucrose buffer [ $5 \mathrm{~mm}$ Tris, $250 \mathrm{~mm}$ sucrose, $1 \mathrm{~mm}$ EGTA, $\mathrm{pH} 7.4$, and a cocktail of proteinase inhibitors (Boehringer Mannheim)] with a potter homogenize and spun at 12,000 $\times$ $g$ at $4^{\circ} \mathrm{C}$ for $10 \mathrm{~min}$. The supernatant was taken and further centrif uged for $30 \mathrm{~min}$ at $100,000 \times \mathrm{g}$ at $4^{\circ} \mathrm{C}$. Proteins were denatured and reduced by boiling in sample buffer containing a final concentration of $2 \%$ SDS and $1 \%$ 2-ME separated on $4-20 \%$ Tris-glycine gels (Novex). $\mathrm{N}$ - and 
A

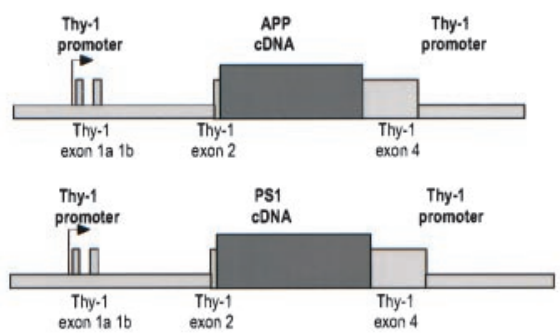

C
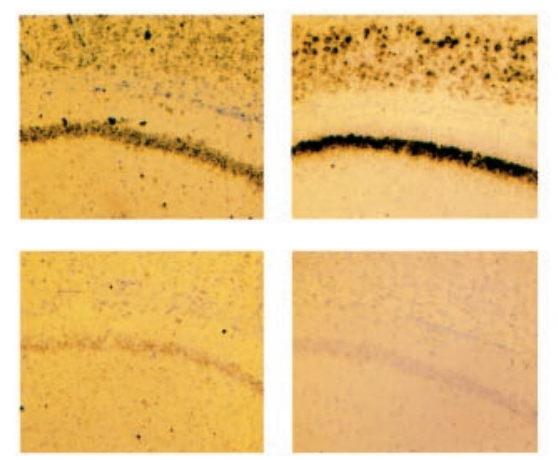

B

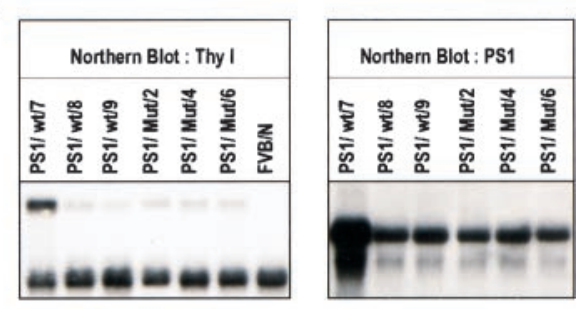

D

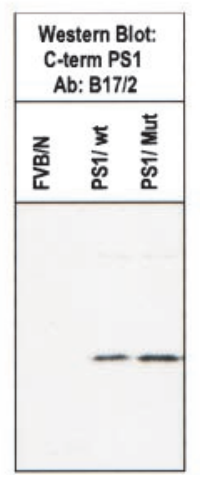

Figure 4. Generation and characterization of wild-type and mutant PS1 transgenic mice. $A$, Schematic representation of the mouse thy1 gene promoter construct, with the APP cDNA, the wild-type PS1 cDNA, or mutant PS1 cDNA. $B$, Northern blotting of total brain RNA from heterozygous PS1 transgenic mice of line PS1/Wt/7 (lane 1), $\mathrm{PS} 1 / \mathrm{Wt} / 8$ (lane 2), PS1/Wt/9 (lane 3), PS1/ Mut/2 (lane 4), PS1/Mut/4 (lane 5), PS1/ Mut/6 (lane 6), and a nontransgenic FVB/N control mouse (lane 7). In transgenic mice, the endogenous PS1 transcript of $2.7 \mathrm{~kb}$ and the transgene transcript of 4.1 $\mathrm{kb}$ are detected with a PS1 probe $(B$, right $)$, with the larger size attributable to the $5^{\prime}$ and $3^{\prime}$ untranslated regions of the thy 1 gene. Detection with a mouse thy 1 gene exon 4 probe $(B$, left $)(1.4 \mathrm{~kb}$ ApaI fragment) detected the $1.9 \mathrm{~kb}$ Thy-1 mRNA and the 4.1 kb PS1 mRNA. $C$, In situ hybridization with a murine PS1 probe (left panels) and a human APP probe (right panels) of brain sections of double (APP/V717I $\times$ PS1/Mut) transgenic (top panels) and nontransgenic (bottom panels) mice reveals overexpression of presenilin 1 and expression of human APP in neurons of the hippocampus (CA1) and cortex. $D$, Western blot with specified antibodies for the C-terminal fragments $(\sim 20 \mathrm{kDa})$ and N-terminal fragments $(\sim 30$ $\mathrm{kDa}$ ) of human PS1 (De Strooper et al., 1997) in extracts of brain from heterozygous wild-type PS1 (PS1/Wt/7) and homozygous mutant PS1 (PS1/Mut/2) mice.
C-terminal fragments of PS1 were detected with the polyclonal antibodies B14/5 and B17/2, respectively (De Strooper et al., 1997).

ELISA for soluble and plaque-associated amyloid peptides. The extracted protein fractions were applied on small reversed phase columns (C18-Seppack cartridges; Waters Associates, Milford, MA) and washed with increasing concentrations of acetonitrile $(5,25$, and $50 \%$ ) containing $0.1 \%$ trifluoroacetic acid. The last fraction contained the amyloid peptides, was dried in vacuum overnight, and dissolved for measurements in ELISA Sandwich ELISA for $A \beta 40$ and $A \beta 42$ peptides was performed using the capture antisera CFA3340 (Barelli et al., 1997) and 21F12, respectively, and were developed with the biotinylated monoclonal antibody 3D6 (De Strooper et al., 1998; Vanderstichele et al., 1998). These ELISA techniques are essentially the same tests as used for diagnostic purposes, with only minor modifications of the initial sample preparation.

In situ hybridization. Paraffin sections $(6 \mu \mathrm{m})$ of double (APP/V717I $\times$ PS1/Mut) transgenic mice and nontransgenic mice were transferred on silanylated glass slides, dewaxed, and rehydrated through an ethanol series. Sections were digested with proteinase $\mathrm{K}(20 \mu \mathrm{g} / \mathrm{ml})$, post-fixed in $4 \%$ paraformaldehyde, and treated with $0.25 \%$ acetic anhydride in $0.1 \mathrm{~mol} / 1$ triethanolamine-HCl. Sections were hybridized overnight in 50\% demonized formamide, $0.3 \mathrm{~mol} / 1 \mathrm{NaCl}, 20 \mathrm{mmol} / 1$ Tris- $\mathrm{HCl}$, and $5 \mathrm{mmol} / 1$ EDTA, pH 8.0, with $10 \%$ dextran sulfate, $1 \times$ Denhardt's solution, 0.5 $\mathrm{mg} / \mathrm{ml}$ yeast RNA, and $10 \mathrm{mmol} / 1$ dithiothreitol and supplemented with the appropriate radiolabeled riboprobe. After stringency washes and ribonuclease A treatment, sections were dehydrated and dipped in photographic emulsion (LM-1; Amersham Pharmacia Biotech, Little Chalfont, UK) and exposed for 1 week. For synthesis of the sense and antisense PS1 RNA, a 221 bp PCR product from exon 7 of the presenilin1 gene was cloned in a pGEM-T vector (Promega, Madison, WI). The sense and antisense human APP RNA probes used were synthesized from a pGEM-T vector (Promega) in which a $263 \mathrm{bp} \mathrm{PCR} \mathrm{product} \mathrm{from} \mathrm{the}$ human APP gene was cloned. The sequences of the upper and the lower primer used in the PCR were 5'-GACTCATGGTGGGCGGTGTTGT-3' and 5'-CCGATGGGTAGTGAAG CAATGGTT-3', respectively. The plasmid was linearized with either NotI or SphI and transcribed with T7 and SP6RNA polymerase, respectively, in the presence of $\left.{ }^{33} \mathrm{P}\right] \mathrm{UTP}$.

Histology and immunohistochemistry. Brain tissue was fixed overnight in $4 \%$ paraformaldehyde at $4^{\circ} \mathrm{C}$, rinsed in PBS, dehydrated, embedded in paraffin, and sectioned. Immunohistochemistry was performed on dewaxed sections after rehydration and quenching of endogenous peroxidase ( $1 \%$ hydrogen peroxide in $50 \%$ methanol, $30 \mathrm{~min}$, room temperature). Immunostaining for the amyloid peptides was performed with antibody FCA18 (Barelli et al., 1997) after microwave treatment of the sections in 10 mM sodium citrate, $\mathrm{pH}$ 6, for $8 \mathrm{~min}$ at an output of $450 \mathrm{~W}$. After incubation for $1 \mathrm{hr}$ in blocking buffer ( $10 \%$ goat serum in $10 \mathrm{~mm}$ Tris, $\mathrm{pH} 7.4,0.15 \mathrm{M}$ $\mathrm{NaCl}$, and $0.1 \%$ Triton $\mathrm{X}-100$ ), appropriately diluted primary antibody was applied and incubated overnight at room temperature. After rinsing and incubation with appropriate secondary antibodies $(1 \mathrm{hr}$, room temperature), immune complexes were detected by incubation with diaminobenzidine and hydrogenperoxide (Moechars et al., 1999a). Thiofla- vine S staining was performed on paraffin sections according to standard protocols.

\section{RESULTS}

\section{Brain amyloid peptides in aging APP/V717I transgenic mice}

Brain amyloid peptides $\mathrm{A} \beta 40$ and $\mathrm{A} \beta 42$ were measured by specified ELISA on protein fractions, differentially extracted from brain of APP/V717I transgenic mice to represent soluble and plaqueassociated amyloid peptides. Biochemical analysis on one hemisphere was paralleled by immunohistochemistry on the other hemisphere to define the extent of the pathology in the different age groups (Moechars et al., 1999a; Van Dorpe et al., 2000).

Compared with older mice, the levels of soluble $\mathrm{A} \beta 40$ and $\mathrm{A} \beta 42$ were relatively low in young APP/V717I transgenic mice of 3 and 6-9 months of age, with a similar $\mathrm{A} \beta 42 / \mathrm{A} \beta 40$ ratio of $<0.4$ (Fig. $1 A)$. In APP/V717I transgenic mice of 15 months of age, the soluble amyloid peptides were increased with an order of magnitude compared with young mice, with the most pronounced increase in $\mathrm{A} \beta 42$ as reflected in the $\mathrm{A} \beta 42 / \mathrm{A} \beta 40$ ratio of $0.67 \pm 0.08$ (Fig. $1 A$ ). The levels of plaque peptides, operationally defined as extracted with the chaotrope guanidinium chloride, increased exponentially in the brain of old mice (Fig. $1 B$ ), which is evidently the biochemical equivalent of amyloid plaque deposition as detected histochemically (Fig. 2) (Moechars et al., 1999a; Van Dorpe et al., 2000). Again, the relative increase was most pronounced for $\mathrm{A} \beta 42$, whereas $\mathrm{A} \beta 40$ remained the predominant peptide (Fig. $1 B$ ).

The data demonstrated that aging of the APP/V717I transgenic mice recapitulated the increase in soluble amyloid peptides (Lue et al., 1999; Teller et al., 1996), as well as the exponential increase in precipitated amyloid peptides (Funato et al., 1998; Lue et al., 1999) as reported in AD patients. The current data extend the findings obtained in two other unrelated APP transgenic mice (Hsiao et al., 1996; Johnson-Wood et al., 1997).

\section{Brain APPm, APPs $\alpha, A P P s \beta$, and $\beta$-C stubs in aging APP/V717I transgenic mice}

To determine how aging affected the processing of APP, we measured brain levels of membrane-bound APPm of $\alpha$ - and $\beta$-secreted APP (APPs $\alpha$ and APPs $\beta$ ) and the cellular $\beta$-C stubs resulting from 

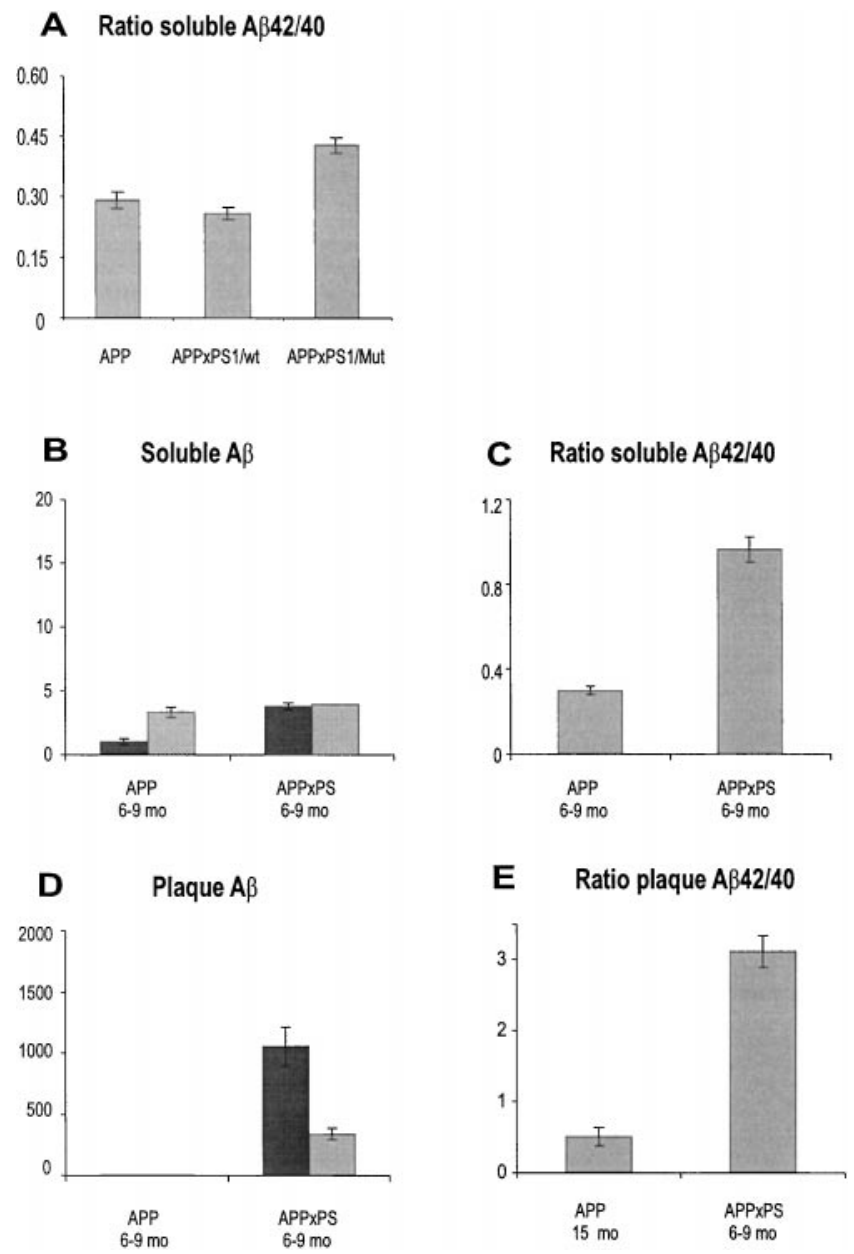

Figure 5. Comparative analysis of levels of soluble and plaque-associated amyloid peptides in the brain of single APP/V717I and double APP V717I $\times$ PS1/A246E transgenic mice. $A$, Ratio of soluble A $\beta 42 / \mathrm{A} \beta 40$ in brain of 6-week-old single APP/V717I $(A P P)$ and double transgenic mice, coexpressing APP/V717I with either wild-type PS1 $(A P P \times P S 1 / w t)$ or mutant PS1 (APP $\times P S 1 / M u t)$. B, Levels of soluble $\mathrm{A} \beta 40$ (gray bars) and $\mathrm{A} \beta 42$ (black bars) in the brain of single APP/V717I $(A P P)$ and double APP/ V717I $\times$ PS1/Mut $(A P P \times P S)$ transgenic mice, all 6-9 months old, and their ratio as calculated $(C)$. $D$, Levels of plaque-associated $\mathrm{A} \beta 40$ (gray bars) and $\mathrm{A} \beta 42$ (black bars) in single and double transgenic mice, all 6-9 months old. $E$, Comparison of the $\mathrm{A} \beta 42 / \mathrm{A} \beta 40$ ratio of insoluble amyloid peptides in brain of single (APP/V717I) 15 -month-old and double transgenic $(A P P / V 717 I \times P S 1 / M u t)$ 6- to 9-month-old mice (at a comparable stage of amyloid plaque formation). All peptides were measured by specified ELISA and are shown as absolute levels (nanograms per gram of wet brain tissue) (left) and the ratio of $\mathrm{A} \beta 42 / \mathrm{A} \beta 40$ calculated (right). All histograms represent the mean with SEM of at least three transgenic mice in each group.

$\beta$-cleavage of APPm (Selkoe, 1998). Previously, we demonstrated that brain levels of mRNA coding for endogenous mouse APP and for transgenic APP increased slightly with age (Moechars et al., 1996, 1999b). This was now extended to the protein level, because membrane-bound APP protein was found to increase with age (Fig. $3 A$ ), similar to and in close parallel with mRNA levels (Moechars et al., 1999b). This increase was specific for APP, because the level of the $85 \mathrm{kDa}$ subunit of the LRP remained constant (Fig. 3A). LRP was considered a suitable internal control because it is unrelated to APP and is also a large membrane-bound protein, ubiquitously expressed in neurons. Normalization for the difference in expression of APPm in all mice in all age groups demonstrated that neither the secreted APPs $\alpha$ (Fig. 3B) and APPs $\beta$ (Fig. 3C) nor the cellular $\beta$-C stubs (Fig. 3D) were affected by aging in APP/V717I transgenic mice.

Surprisingly then, the current data indicated that aging did not favor $\beta$ - over $\alpha$-secretase cleavage of APPm to produce more of the $\beta$-C stubs that are the obligatory precursors of the amyloid peptides (Selkoe, 1998). This left the possibility that increased amyloid peptide concentration and deposition was attributable to altered $\gamma$-secretase activity.

Because mutant presenilins that cause familial early-onset AD have been proposed to affect $\gamma$-secretase activity (Borchelt et al., 1996; Duff et al., 1996; Scheuner et al., 1996; Borchelt et al., 1997; Citron et al., 1997; Holcomb et al., 1998), we tested the hypothesis that aging disturbed APP metabolism at the $\gamma$-secretase step as controlled by PS1.

\section{Double transgenic mice coexpressing APP/V717I and wild-type or mutant human PS1}

Transgenic mice were generated that express human wild-type PS1 or the EOFAD mutant PS1/A246E under the transcriptional control of the mouse thy1 gene promoter, in the $\mathrm{FVB} / \mathrm{N}$ mouse genetic background, the same strategy as used to generate the APP/V717I transgenic mice (Fig. 4A) (Moechars et al., 1999a). This warranted coexpression of the transgenes in the same cells, namely neurons (Fig. 4C). Three and six founders were generated for PS1 and PS1/A246E, respectively, that stably transmitted and expressed the transgenes (Fig. 4). Western blotting demonstrated normal and complete processing by the presence of $\mathrm{C}$ - and N-terminal fragments of human wild-type and mutant PS1 (Fig. 4D). For the purpose of the current experiments, wild-type and mutant PS1 transgenic mice were crossed with the APP/V717I transgenic mice, and double transgenic mice were identified by standard methods of genotyping (Moechars et al., 1999a).

In double transgenic mice, overexpression of EOFAD mutant PS1 but not human wild-type PS1 increased the A $\beta 42 / A \beta 40$ ratio, even in young mice, as observed by others (Borchelt et al., 1996; Duff et al., 1996; Citron et al., 1997) (Fig. 5A). We further confirmed that amyloid deposition occurred at the younger age of 6-9 months in double transgenic mice with mutant PS1 compared with 12-15 months in single APP/V717I transgenic mice (Fig. 2) (Moechars et al., 1999a; Van Dorpe et al., 2000).

\section{Brain amyloid peptides and APP metabolites in aging double transgenic mice}

Double transgenic mice, i.e., APP/V717I $\times$ PS1/A246E, differed in three major aspects from single APP/V717I transgenic mice when comparatively analyzed at the ages of $6-9$ and 15 months, respectively (Fig. 5). First, mutant PS1 hardly affected A $\beta 40$ but considerably increased the level of $\mathrm{A} \beta 42$ when single and double transgenic mice of the same age were compared (Fig. $5 B$ ). The A $\beta 42 /$ $\mathrm{A} \beta 40$ ratio of soluble peptides increased from $0.30 \pm 0.04$ to $0.96 \pm$ 0.06 , respectively, in single and double transgenic mice of 6-9 months of age (Fig. $5 C$ ). Second, plaque-associated amyloid pep-
Figure 6. Western blotting for neprilysin in brain of aging APP/V717I transgenic mice. Western blotting on membrane proteins extracted from brain of nontransgenic $\mathrm{FVB} / \mathrm{N}$ mice $(A)$ and APP/V717I transgenic mice $(B)$ at the indicated ages. The Western blots also illustrate serial dilutions of a standardized pooled extract as applied on each gel to allow normalization.

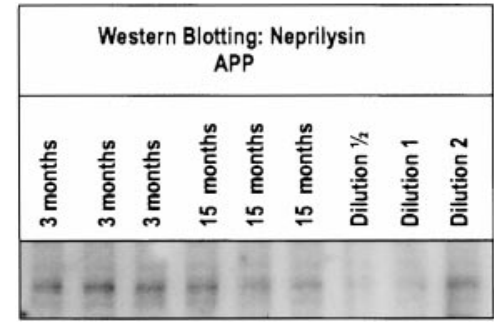

\begin{tabular}{|c|c|c|c|c|c|c|c|c|}
\hline \multicolumn{9}{|c|}{$\begin{array}{c}\text { Western Blotting: Neprilysin } \\
\text { FVB/N }\end{array}$} \\
\hline $\begin{array}{l}\text { 号 } \\
\text { 总 } \\
\text { E્m }\end{array}$ & 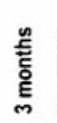 & 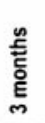 & $\begin{array}{l}\stackrel{n}{E} \\
\text { Ẽ } \\
\text { É } \\
\stackrel{2}{n}\end{array}$ & 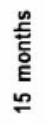 & 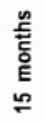 & 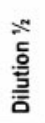 & $\begin{array}{l}\bar{c} \\
\overline{\frac{o}{3}} \\
\overline{\bar{z}}\end{array}$ & 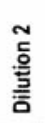 \\
\hline$=$ & - & $=$ & - & $=$ & - & - & - & - \\
\hline
\end{tabular}


tides were undetectable in single APP/V717I transgenic mice at the age of 6-9 months but were dramatically high in the brain of double transgenic mice (Fig. 5D). Again, this is the evident biochemical correlate of the much earlier development of amyloid plaques in the double transgenic mice (Fig. 2). Finally, the most clear-cut demonstration of the effect of mutant PS1 was the completely inversed ratio of plaque $\mathrm{A} \beta$ peptides. $\mathrm{A} \beta 42$ was predominant in the plaques of double transgenic mice at $6-9$ months of age compared with $\mathrm{A} \beta 40$ in those of single APP/V717I transgenic mice at 15 months. This was most clearly marked by the exceptionally high plaque $\mathrm{A} \beta 42 / \mathrm{A} \beta 40$ ratio of $3.11 \pm 0.22$ in double transgenic mice compared with $0.43 \pm 0.07$ in single APP/V717I transgenic mice (Fig. 5E).

The marked differences in APP metabolism in the brain of the double mutant APP $\times$ PS1 transgenic mice argued strongly for the thesis that aging in the single APP/V717I transgenic mice was mechanistically different from the effect exerted by the coexpression of the mutant PS1 transgene.

\section{DISCUSSION}

In summary, we have demonstrated that none of the known metabolites of APP, i.e., APPm, APPs $\alpha$, APPs $\beta$, and the $\beta$-C stubs, correlated with the dramatic increased levels of the amyloid peptides $\mathrm{A} \beta 40$ and $\mathrm{A} \beta 42$, soluble or precipitated as amyloid plaques, in the brain of aging APP/V717I transgenic mice. We tested and refuted the hypothesis that aging acted by presenilin 1 as or on the elusive $\gamma$-secretase to increase production of amyloid peptides by analyzing double transgenic mice. In this respect, it must be stressed that, in the double transgenic mice, the pathological impact of the combination was evident; in the brain of double transgenic mice containing mutant PS1, but not wild-type human PS1, the formation of amyloid plaques was already observed from 6 months of age onward. Biochemically, we have confirmed and extended findings in other transgenic mice (Borchelt et al., 1996, 1997; Duff et al., 1996; Citron et al., 1997; Holcomb et al., 1998) that this was specifically attributable to increased accumulation of $\mathrm{A} \beta 42$ at this earlier age. This confirmed in vivo the original defined cell biological effect of the EOFAD PS1 mutations on APP metabolism (Citron et al., 1998) (for review, see Selkoe, 1998)

In the absence of any indication for a major metabolic shift to the amyloidogenic pathway, aging must be proposed to act otherwise. The hypothesis developed during the course of this work that clearance and degradation of amyloid peptides rather than increased production was the primary problem in the brain of aging APP/V717I transgenic mice. This coincided with renewed emphasis on degradation and clearance of amyloid peptides (Glabe, 2000) after the identification of neprilysin as a potential candidate proteinase (Iwata et al., 2000). Judged from Western blots, the level of neprilysin was, however, not decreased in the brain of aged APP/ V717I transgenic mice (Fig. 6). Evidently, many other proteinases, e.g., insulin degrading enzyme (Vekrellis et al., 2000) or proteinase inhibitors, as well as clearance mediated by diverse carrier proteins and receptors, could become functionally or structurally compromised with aging and alone or in combination explain our observations. The great diversity of potential candidates will make it difficult to define their functional importance and identity.

On the other hand, it is conceivable that effective removal of amyloid peptides could involve or be mediated by many different intracellular and extracellular proteins. The genetic and epidemiological evidence for the involvement in or association with sporadic or late onset $\mathrm{AD}$ of many different genes, encoding a functional wide variety of proteins, would find a plausible explanation in this hypothesis. This also might functionally connect with the proven involvement of apolipoprotein E, and eventually even of $\alpha$-2-macroglobulin, and their common receptor in brain, the LRP. Other mechanisms are likely at work, and alternatively we must consider other catabolic pathways for the amyloid peptides (Vekrellis et al., 2000; Iwata et al., 2000; Glabe, 2000) while these and other as yet unknown degradation and clearance mechanisms could become compromised in aging brain. Their precise definition and their quantitative approximation in aging brain constitutes the most interesting and challenging sequel to our current observations.

\section{REFERENCES}

Barelli H, Lebeau A, Vizzavona J, Delaere P, Chevallier N, Drouot C, Marambaud P, Ancolio K, Buxbaum JD, Khorkova O, Heroux J, Sahasrabudhe S, Martinez J, Warter JM, Mohr M, Checler F (1997) Characterization of new polyclonal antibodies specific for 40 and 42 amino acid-long amyloid beta peptides: their use to examine the cell biology of presenilins and the immunohistochemistry of sporadic Alzheimer's disease and cerebral amyloid angiopathy cases. Mol Med 3:695-707.

Borchelt DR, Thinakaran G, Eckman CB, Lee MK, Davenport F, Ratovitsky T, Prada CM, Kim G, Seekins S, Yager D, Slunt HH, Wang R, Seeger M, Levey AI, Gandy SE, Copeland NG, Jenkins NA, Price DL, Younkin SG, Sisodia SS (1996) Familial Alzheimer's disease-linked presenilin 1 variants elevate Abeta1-42/1-40 ratio in vitro and in vivo. Neuron 17:1005-1013.

Borchelt DR, Ratovitski T, van Lare J, Lee MK, Gonzales V, Jenkins NA, Copeland NG, Price DL, Sisodia SS (1997) Accelerated amyloid deposition in the brains of transgenic mice coexpressing mutant presenilin 1 and amyloid precursor proteins. Neuron 19:939-945.

Citron M, Westaway D, Xia W, Carlson G, Diehl T, Levesque G, JohnsonWood K, Lee M, Seubert P, Davis A, Kholodenko D, Motter R, Sherrington R, Perry B, Yao H, Strome R, Lieberburg I, Rommens J, Kim S, Schenk D, Fraser P, St. George Hyslop P, Selkoe DJ (1997) Mutant presenilins of Alzheimer's disease increase production of 42-residue amyloid beta-protein in both transfected cells and transgenic mice. Nat Med 3:67-72.

Citron M, Eckman CB, Diehl TS, Corcoran C, Ostaszewski BL, Xia W, Levesque G, St. George Hyslop P, Younkin SG, Selkoe DJ (1998) Additive effects of PS1 and APP mutations on secretion of the 42-residue amyloid beta-protein. Neurobiol Dis 5:107-116.

De Strooper B, Simons M, Multhaup G, Van Leuven F, Beyreuther K, Dotti CG (1995) Production of intracellular amyloid-containing fragments in hippocampal neurons expressing human amyloid precursor protein and protection against amyloidogenesis by subtle amino acid substitutions in the rodent sequence. EMBO J 14:4932-4938.

De Strooper B, Beullens M, Contreras B, Levesque L, Craessaerts K, Cordell B, Moechars D, Bollen M, Fraser P, George-Hyslop PS, Van Leuven F (1997) Phosphorylation, subcellular localization, and membrane orientation of the Alzheimer's disease-associated presenilins. J Biol Chem 272:3590-3598.

De Strooper B, Saftig P, Craessaerts K, Vanderstichele H, Guhde G, Annaert W, Von Figura K, Van Leuven F (1998) Deficiency of presenilin1 inhibits the normal cleavage of amyloid precursor protein. Nature 391:387-390.

Duff K, Eckman C, Zehr C, Yu X, Prada C-M, Perez-tur J, Hutton M, Buee L, Harigaya Y, Yager D, Morgan D, Gordon MN, Holcomb L, Refolo L, Zenk B, Hardy J, Younkin S (1996) Increased amyloidbeta42(43) in brains of mice expressing mutant presenilin 1 . Nature 383:710-713.

Funato H, Yoshimura M, Kusui K, Tamaoka A, Ishikawa K, Ohkoshi N, Namekata K, Okeda R, Ihara Y (1998) Quantitation of amyloid betaprotein (A beta) in the cortex during aging and in Alzheimer's disease. Am J Pathol 152:1633-1640.

Glabe C (2000) Does Alzheimer disease tilt the scales of amyloid degradation versus accumulation? Nat Med 6:133-134.

Haass C, Schlossmacher M, Hung AY, Virgo-Pelfrey C, Mellon A, Ostazewski B, Lieberburg I, Koo E, Schenk D, Teplow D, Selkoe DJ (1992) Amyloid beta-peptide is produced by cultured cells during normal metabolism. Nature 359:322-325.

Hardy J (1997) Amyloid, the presenilins and Alzheimer's disease. Trends Neurosci 20:154-159.

Holcomb L, Gordon M, McGowan E, Yu X, Benkovic S, Jantzen P, Wright K, Saad I, Mueller R, Morgan D, Sanders S, Zehr C, O'Campo K, Hardy J, Prada C, Eckman C, Younkin S, Hsiao K, Duff K (1998) Accelerated Alzheimer-type phenotype in transgenic mice carrying both mutant amyloid precursor protein and presenilin 1 transgenes. Nat Med 4:97-100.

Howland DS, Savage MJ, Huntress FA, Wallace RE, Schwartz DA, Loh T, Melloni RH Jr, DeGennaro LJ, Greenberg BD, Siman R, Swanson ME, Scott RW (1995) Mutant and native human beta-amyloid precursor proteins in transgenic mouse brain. Neurobiol Aging 16:685-699.

Hsiao K, Borchelt DR, Olson K, Johannsdottir R, Kitt C, Yunis W, Xu S, Eckman C, Younkin S, Price D, Iadecola C, Clark HB, Carlson G (1995) Age-related CNS disorder and early death in transgenic $\mathrm{FVB} / \mathrm{N}$ mice overexpressing Alzheimer amyloid precursor proteins. Neuron 15:1203-1218.

Hsiao K, Chapman P, Nilsen S, Eckman C, Harigaya Y, Younkin S, Yang F, Cole G (1996) Correlative memory deficits, Abeta elevation, and amyloid plaques in transgenic mice. Science 274:99-102

Ida N, Hartmann T, Pantel J, Schröder J, Zerfass R, Förstl H, Sandbrink R, Masters CL, Beyreuther K (1996) Analysis of heterogeneous A4 peptides in human cerebrospinal fluid and blood by a newly developed sensitive Western blot assay. J Biol Chem 271:22908-22914. 
Iwata N, Tsubuki S, Takaki Y, Watanabe K, Sekiguchi M, Hosoki E, Kawashima-Morishima M, Lee HJ, Hama E, Sekine-Aizawa Y, Saido TC (2000) Identification of the major Abeta1-42-degrading catabolic pathway in brain parenchyma: suppression leads to biochemical and pathological deposition. Nature 6:143-150.

Johnson-Wood KLM, Motter R, Hu K, Gordon G, Barbour R, Khan K, Gordon M, Tan H, Games D, Lieberburg I, Schenk D, Seubert P, McConlogue L (1997) Amyloid precursor protein processing and A beta42 deposition in a transgenic mouse model of Alzheimer disease. Proc Natl Acad Sci USA 94:1550-1555.

Kimberly WT, Xia W, Rahmati T, Wolfe MS, Selkoe DJ (2000) The transmembrane aspartates in presenilin 1 and 2 are obligatory for gamma-secretase activity and amyloid beta-protein generation. J Biol Chem 275:3173-3178.

Li YM, Lai MT, Xu M, Huang Q, DiMuzio-Mower J, Sardana MK, Shi XP, Yin KC, Shafer JA, Gardell SJ (2000) Presenilin 1 is linked with gamma-secretase activity in the detergent solubilized state Proc Nat Acad Sci USA 97:6138-6143.

Lue LF, Kuo YM, Roher AE, Brachova L, Shen Y, Sue L, Beach T, Kurth JH, Rydel RE, Rogers J (1999) Soluble amyloid beta peptide concentration as a predictor of synaptic change in Alzheimer's disease. Am J Pathol 155:853-862.

Moechars D, Lorent K, De Strooper B, Dewachter I, Van Leuven F (1996) Expression in brain of amyloid precursor protein mutated in the alphasecretase site causes disturbed behavior, neuronal degeneration and premature death in transgenic mice. EMBO J 15:1265-1274.

Moechars D, Lorent K, Dewachter I, Baekelandt V, De Strooper B, Van Leuven F (1998a) Transgenic mice expressing an alpha-secretion mutant of the amyloid precursor protein in the brain develop a progressive CNS disorder. Behav Brain Res 95:55-64.

Moechars D, Gilis M, Kuiperi C, Laenen I, Van Leuven F (1998b) Aggressive behaviour in transgenic mice expressing APP is alleviated by serotonergic drugs. NeuroReport 9:3561-3564.

Moechars D, Dewachter I, Lorent K, Reverse D, Baekelandt V, Naidu A, Tesseur I, Spittaels K, Haute CV, Checler F, Godaux E, Cordell B, Van Leuven F (1999a) Early phenotypic changes in transgenic mice that overexpress different mutants of amyloid precursor protein in brain. J Biol Chem 274:6483-6492.
Moechars D, Lorent K, Van Leuven F (1999b) Premature death in transgenic mice that overexpress a mutant amyloid precursor protein is preceded by severe neurodegeneration and apoptosis. Neuroscience 91:819-830.

Scheuner D, Eckman C, Jensen M, Song X, Citron M, Suzuki N, Bird TD, Hardy J, Hutton M, Kukull W, Larson E, Levy-Lahad E, Viitanen M, Peskind E, Poorkaj P, Schellenberg G, Tanzi R, Wasco W, Lannfelt L, Selkoe D, Younkin S (1996) Secreted amyloid beta-protein similar to that in the senile plaques of Alzheimer's disease is increased in vivo by the presenilin 1 and 2 and APP mutations linked to familial Alzheimer's disease. Nat Med 2:864-870.

Selkoe D (1998) The cell biology of beta-amyloid precursor protein and presenilin in Alzheimer's disease. Trends Cell Biol 8:447-453.

Selkoe DJ, Wolfe MS (2000) In search of gamma-secretase: presenilin at the cutting edge. Proc Natl Acad Sci USA 97:5690-5692.

Teller J, Russo C, DeBusk LM, Angelini G, Zaccheo D, Dagna-Bricarelli F, Scartezzini P, Bertolini S, Mann DMA, Tabaton M, Gambetti P (1996) Presence of soluble amyloid beta-peptide precedes amyloid plaque formation in Down's syndrome. Nat Med 2:93-95.

Van Dorpe J, Smeijers L, Dewachter I, Nuyens D, Spittaels K, Van den Haute C, Mercken M, Moechars D, Laenen I, Kuiperi C, Bruynseels K, Tesseur I, Loos R, Vanderstichele H, Checler F, Sciot R, Van Leuven F (2000) Prominent cerebral amyloid angiopathy in transgenic mice overexpressing the London mutant of human APP in neurons. Am J Pathol, in press.

Vanderstichele H, Blennow K, D'Heuvaert N, Buyse M-A, Wallin A, Andreasen N, Seubert P, Van De Voorde A, Vanmechelen E (1998) Development of a specific diagnostic test for measurement of $\beta$-amyloid (1-42) in CSF. Progress in Alzheimer's and Parkinson's diseases (Fisher A, Hanin I, Yoshida M, eds), pp 773-778. New York: Plenum.

Vekrellis K, Ye Z, Qiu WQ, Walsh D, Hartley D, Chesneau V, Rosner MR, Selkoe DJ (2000) Neurons regulate extracellular levels of amyloid betaprotein via proteolysis by insulin-degrading enzyme. J Neurosci 20:1657-1665.

Wolfe MS, Xia W, Ostaszewski BL, Diehl TS, Kimberly WT, Selkoe DJ (1999) Two transmembrane aspartates in presenilin-1 required for presenilin endoproteolysis and gamma-secretase activity. Nature 398:513-517. 